\title{
The Impact of Weblogs on Teaching Translation: Yemeni Learners' Attitudes and Perceptions
}

\section{Marwan Alalimi}

ESL Instructor, Curriculum and Instruction Department, College of Education, King Saud University

Riyadh, Saudi Arabia, teachermarwan121@gmail.com

\begin{abstract}
This study aimed to elicit EFL learners' attitudes and perceptions on the implementation of weblogs in the course of translation from and into Arabic/English. The study adopted the descriptive research design, and a questionnaire was used for data collection. The participants were eleven female students in their fourth year in the English department. They were taught a translation course from and into Arabic/English by the researcher. Utilizing weblogs in the course of translation was an out-class project as a supportive material to a traditional translation class. Translation assignments were posted on the weblog weekly by the instructor, and learners were asked to visit the weblog, translate the posted text, and give feedback to their peers' translations. At the end of the program, learners were handed out the questionnaire to find out their attitudes and perceptions on the effectiveness and usefulness of using weblogs in translation. Results showed that the learners have positive attitudes towards implementing weblog in translation class.
\end{abstract}

Keywords: attitudes, perceptions, weblog, translation, EFL learners

\section{INTRODUCTION}

Recent years have revealed a great tendency towards adopting social applications in education. The most ubiquitous ones are those within web 2.0 applications such as weblogs, wikis, social networking, RSS, and pod-casting. They have received a tremendous attention in education in general (Pinkman, 2005; Alshumaimeri, 2008; Richardson, 2010; Schroeder, Minocha \& Schneider, 2010; Amir, Ismail \& Hussin, 2011; Roussinos \& Jimoyiannis, 2011; Grami, 2012; Jimoyiannis \& Angelaina, 2012; Lin, Groom \& Lin, 2013). This is a normal and natural tendency towards web-assisted education, because the educational process, including all its dimensions, should always be in a continuous progression especially when it comes to keeping up with the advancement of technology.

Blogging which is considered as one of the most well-known social applications has attracted the researcher's attention to investigate its effectiveness on translation process in the context of English and Arabic languages. It had the priority to be implemented in this study because it is an easily used and freely accessed application that can be utilized by teachers and learners to facilitate learning. Moreover, a weblog has a number of common yet special features which makes it surpass other applications of web 2.0 including: (1) creating a type of website in an easy, cheap and quick way; (2) organizing content chronologically backwards and by postings which are usually short and frequently posted; (3) allowing readers' voices to be heard through a "comments" feature; (4) instant publishing to the web without having to learn HTML or use a web authoring program; (5) viewing related links; and (6) clearly presenting author's voice and personality (Wu, 2006).

Considering the abovementioned features of weblogs, bilingual instructors and translators, shall try out

Citation: Alalimi, M. (2020). The Impact of Weblogs on Teaching Translation: Yemeni Learners' Attitudes and Perceptions. Anatolian Journal of Education, 5(2), 59-72. https://doi.org/10.29333/aje.2020.525a 
such new web application and find out its effectiveness on teaching EFL major subjects; starting from general language skills to other core linguistic subjects such as translation. Therefore, the researcher utilized weblogs as a means for teaching translation in order to discover the effectiveness of this type of web-based technology on teaching translation and also to deduce learners' attitudes and observations of this modern and free-accessed technology. The choice of applying this technical tool on teaching translation came from researcher's persuasion that translation has a problematic nature, which as a result should receive careful attention and consideration. Consequently, the use of weblogs in teaching this demanding subject could be advantageous and helpful. In fact, a multitude reservoir of research has been devoted to the contributions of weblogs on teaching language skills especially writing skills (Fellner \& Apple, 2006; Amir, Z. et al., 2011; Aljumah, 2012; Lin \& Lin, 2013). Some other researchers investigated the impact of weblogs on students' engagement and collaborative learning (Liu \& Carless, 2006; Jimoyiannis \& Angelaina, 2012; Taki \& Fardafshari, 2012), and even more, the contribution of weblogs in encouraging learner independence (Pinkman, 2005).

The main purpose of this study was to elicit learners' attitudes towards utilizing blogs in translation teaching and learning. The researcher focused on finding out learners' attitudes because studies which had been executed in finding out learners' or teachers' attitudes, opinions or perceptions were deemed significant in educational settings. Alshumaimeri (2008) clarified that in educational environment, the stated attitudes by either teachers or learners are of crucial importance for achieving the educational objectives, particularly those related to the implementation of new technology.

\section{Problem Statement}

The majority of research, which investigated the impact of weblogs, focused on language skills, especially the writing skills. The other core EFL main college courses such as translation courses have not, according to the researcher's humble knowledge, benefited from new-technology applications such as weblogs and wikis.

Written translation process undoubtedly follows the rules of writing such as sentence structure, cohesion, coherence, and punctuation, which could let us consider it as a type of academic writing. However, it has not received enough research attention in terms of utilizing modern technology applications in comparison with the multitude reservoir of using those up-to-date applications in writing research. Generally speaking, most of Arab countries including Yemen where the researcher had the initial education and Saudi Arabia where the researcher received the tertiary education, translation courses are still taught in the traditional methodology where an instructor brings texts and asks his students to attempt their translation. Then, the instructor gives his feedback.

Despite the fact that translation courses are thought to be the most difficult for the majority of EFL learners, most of the translation research is limited to identifying learners' translation errors and problems. Furthermore, the findings of those studies suggest theoretical solutions which have not been helpful in practice (Al-Hamdallah, 1998; Oro Cabanas, 2012; Al-Nakhalah, 2013). What learners actually need in order to be motivated in translation learning is to be exposed to some of the motivating easy-used and freely-accessed applications such as weblogs. None, according to the researcher's knowledge, investigated the effect of weblogs on translation teaching and learning. Consequently, the researcher wanted to fill this gap by conducting this study, which he hoped would add to the existing blogging and translation research. The researcher conducted this study upon female college students majoring in English as a foreign language in the English department; college of arts, Sana'a University, Distance-learning at Riyadh campus, Saudi Arabia.

\section{Research Questions}

The present study aimed to answer the following three questions: 
1. What type of perceptions and attitudes do learners have towards the implementation of weblogs on the translation course?

2. What are the learners' attitudes towards using weblogs in translation in comparison with the traditional method?

3. What are learners' attitudes towards teacher's and peers' feedback via weblog in translation classes?

\section{Literature Review}

\section{Weblog's Definition and Types}

The Longman Dictionary of Contemporary English defined weblog as a "webpage containing information or opinions from a particular person or about a particular subject, to which new information is added regularly". Another definition given by the free dictionary.com defines it as "a website that displays in chronological order the postings by one or more individuals and usually has links to comments on specific postings". However, a comprehensive definition was proposed by Richardson (2010) who defined a weblog as an easily created, easily updateable website that allows an author (or authors) to publish instantly to the internet from any internet connection. The word weblog can be replaced by blog or blogging. In this study, the three expressions were used interchangeably. All the above-mentioned weblog's definitions are in consensus that it has an interactional feature perceived among authors and participants. The author writes a post and the participants give their feedback by posting their comments.

There are three types of weblogs as Campbell (2003) classified them: tutor blog, learner blog and class blog. By tutor blog, it was meant the blog that could be run by the tutor for the learners. And by the learner blog, it has been referred to the blog that could be run by individual learner or a small group of learners. Regarding the class blog, it was referred to the blog which can be resulted from the collaborative efforts of the entire class. The type of weblog implemented in this study was the first type which was run by the instructor. The instructor posted Arabic and English texts and learners were asked to freely translate them and give feedback by posting their comments on their peers' translations. Finally the teacher gave constructive feedback to all learners.

\section{Weblogs and Collaborative Learning}

Recent research of language teaching and learning showed tendency to student-centred strategies. Collaborative learning has approved its effectiveness as one of the most modern student-centred strategy where learners are not just passive receivers of knowledge, but proactive role-players. Richardson (2010) stated that "one of the biggest potentials of Weblogs is the ability to create spaces where students can collaborate with others online" (p. 23). They are learners and teachers at the same time. They teach each other and can teach the teacher as well. The teacher in this methodology is considered a learner, modifier, organizer but not a controller of the learning situation. Learners in this approach become actively engaged in assignments, tasks or projects. Therefore, their knowledge is constructed collaboratively. Weblogs tremendously contribute to collaborative learning. This type of learning is manifested by learners' engagement, critical thinking, negotiation, deep communication among peers and tutor, and peer and tutor feedback. The capability of weblogs in enhancing collaborative learning was investigated by a lot of researchers (Oravec, 2003; Ward, 2004; Ducate \& Lomicka, 2005; Kim, 2008).

The main and the most prominent feature of collaborative learning is the feedback which reflects learners' engagement in tasks, whether this feedback is given by the instructor or by peers. Regarding peer feedback, Liu and Carless (2006) described peer feedback as a communication process through which learners enter into dialogues related to performance and standards. Moreover, their feedback 
can prompt a collaborative dialogue among learners. However, learners might have their own feedback preference. According to Hyland and Hyland (2006) foreign language learners generally prefer tutor's feedback to peer feedback. The learners may not feel confident to give feedback or feel doubtful receiving their peers' feedback. As a result, they completely trust and value their tutor's feedback. They think that feedback is the tutor's responsibility and role (Hanrahan \& Isaacs, 2001).

\section{Weblogs and Writing Skills}

The majority of blog assisted language learning research has been devoted to English language skills especially the writing skills (Pinkman, 2005; Noytim, 2010; Aljumah, 2012; Yunus, Tuan \& Salehi, 2013). Since weblogs are considered one of the recent web 2.0 tools which has just been known and implied in education for about decade, a lot of researchers were interested in finding out its effectiveness in English language writing skills whether in the context of English as a Second Language (ESL) or English as a Foreign Language (EFL). For instance, Pinkman (2005) conducted an out-of class blog project for a foreign language class composed of 15 students from different departments in Kwansei Gakuin University. The project aimed at improving learners' linguistic performance in English as a foreign language and encouraging learners' independence. The results of this study suggested that learners enjoyed the blog project and their interest and motivation to use English increased. Their linguistic skills have also improved especially the writing and reading skills. Other studies sought to elicit learners' opinions and attitudes toward the implementation of weblogs in English language learning such as the study of Aljumah (2012) who investigated students' attitudes and perceptions toward the use of blog in learning writing in the university level. The results of this study indicated that students had a favorable attitude and perception toward the implementation of blogs in writing class. Similarly, a study executed by Noytim (2010) to find out the potential value of weblog use in learning reading and writing and to investigate learner's perceptions and attitudes towards using weblogs. The findings indicated that using Weblogs did not only enhance learners' reading and writing skills, but they also increased learner's confidence and motivation in writing and learning English. In addition, learners' attitudes were positive toward using weblogs in English. Not only did students like their peers' and teachers' comments, they also liked to exchange ideas and opinions, as well as constructive feedback and teacher correction on their writing. More studies on writing skills such as summary writing, Kitchakarn (2012) found that learners' summary writings have improved and their attitudes towards using weblogs in learning were positive. Taki and Fardafshari (2012) emphasized the practicality of weblogs on writing skills and motivation. Their study concluded that learners' writing ability has improved and learners were engaged actively in their writing assignments.

In contradiction to the previously mentioned studies, a study carried out by Lin, Groom and Lin (2013) reported negative results regarding the peer feedback and learners interaction in the blogging process. Their study explored the experiences of a group of Taiwanese ESL student writers on a course of study that used a blog-assisted language learning (BALL) methodology. The participants were twenty-five first-year English major taking a BALL writing course for a full academic year; 36 weeks; two hours each week. Students were required to post at least 17 assignment entries on their blogs in order to ensure an adequate degree of immersion in this experience. Their findings claimed that participants' blogging activities were found to be inhibited by low L2 proficiency levels, by feelings of anxiety and embarrassment about possible peer reactions to their work, and by the slow pace at which completed compulsory blogging tasks were completed.

\section{Weblogs and Translation Instruction}

Though translation teaching and learning is an arduous process, it hasn't received desirable attention by specialists in terms of implementing modern technology such as wikis, and weblogs in translation instruction. It has been expressed by McDonough Dolmaya (2011) that very little attention has been 
paid to translation and the blogosphere and more specifically to blogs about translation or blogs maintained by professional translation. The researcher found few yet not enough studies which can be related to some extent to the present study. For instance, the study of Perrino (2009) aimed to anticipate the future of translation in a web 2.0 environment. He indicated that user generated tools such as wikis and blogs will not be affecting the professional translation industry because it is not a popular phenomenon. However, it would be in the best interests of professionals and academics to observe its development and to find ways to deal with it. Another study was conducted by Azizinezhad and Hashemi (2011) who investigated the possible advantages and difficulties of using weblogs in translators' points of view. The study wasn't devoted to using blogs in teaching and learning translation. It only presented different views of several researchers expressing the advantages and disadvantages of using blogs in language learning. Moreover, all the researchers' views were concerned about the pros and cons of implementing weblogs in language learning skills such as writing skills and reading comprehension. Another study was conducted by McDonough Dolmaya (2011) who analysed content of translation blogs to illustrate what are the bloggers writing about and what those blogs reveal about translator behaviours and attitudes. The content of the blogs was then analysed to show how it can be used to enhance understanding of the sociology of translation. Her study revealed that blogs' posts were about variant categories such as offering advice which represented $80 \%$ of the total analysed posts. However, $36.2 \%$ of the total posts were about commenting on translations and $34 \%$ were concerned about discussing words, terms of expressions used in translation.

The present study was unlike the previously mentioned studies because it highlighted the effectiveness of weblogs on applied translation learning where learners practiced translation using weblogs. In other words, the blogs designed for this study were devoted to practical translation where learners posted their own translation for the assignments given by the teacher. Also, learners were required to translate and comment on their peers' translations. Though, according to the researcher knowledge at the time of conducting this study, no similar study had touched upon such topic, the researcher hoped that such study would light a candle in the research of translation and blogging.

\section{METHOD}

\section{Context and Participants}

The main aim of this study was to elicit learners' attitudes towards the implementation of weblogs on a translation course. The researcher conducted this study upon advanced EFL learners who were in their last semester of the Bachelor's Program at Sana'a University; college of arts; English language department; distance-learning program at Riyadh campus. The participants were eleven female learners in level four and were studying the third translation course. This course is preceded by two translation courses in the Bachelor's program at the English department. The researcher has taught them translation class for a complete semester; the second semester of the academic year 2014. The weblog project was an out-class project. It lasted for eight weeks; during the first week, learners were introduced to how to use weblogs on the free blogging provider "www.blogger.com". In the second week, Learners were asked to visit their weblog and write their translation in the comment box to the posted text by the researcher. Learners continued posting translation to six different types of texts assigned by the teacher. They also gave their feedback to their peers' translation before the teacher finally gave his feedback to each learner. Since it was desired that learners maximize their engagement and interactions while blogging, the researcher divided the learners into two groups following the recommendations of other researchers such as Pérez-Sabater, Montero-Fleta, and Rising as cited in (Taki \& Fardafshari, 2012), who believe that in small groups there is a better interaction, intimacy, and trust. They also think that small groups facilitate constructive feedback and insightful reflection. Therefore, the purpose of dividing learners into two groups while blogging in this study was only to 
increase their engagement and interactions. In the eighth week, learners were handed out questionnaire and were asked to indicate their honest responses. The following table shows the weblog project schedule.

Table 1

The Weblog Project Schedule

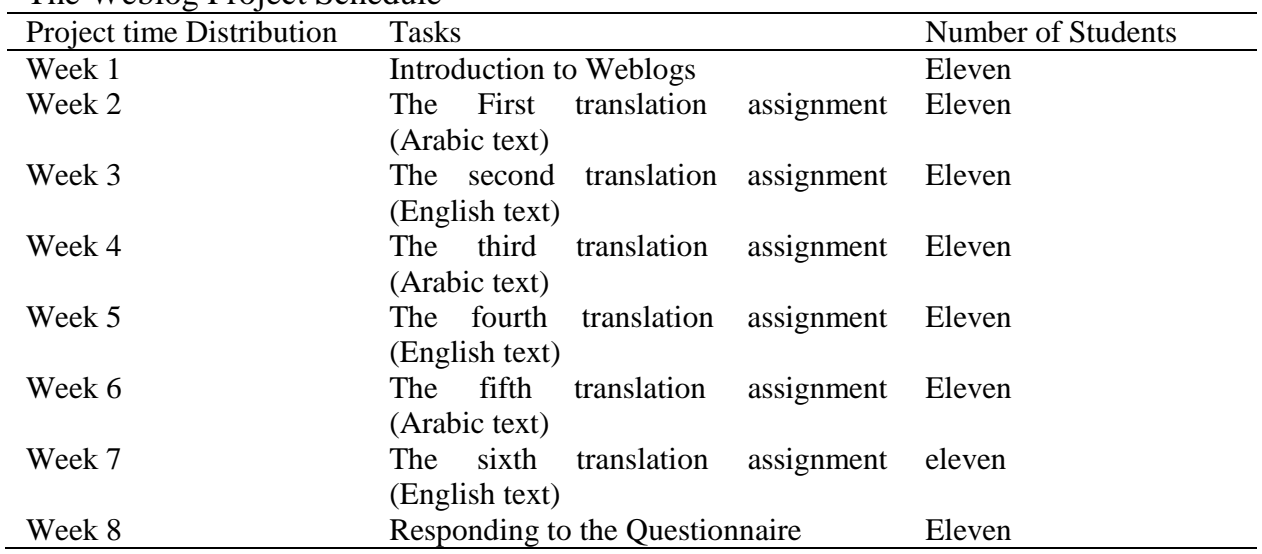

\section{Research Design}

This study adopted the descriptive research design. The researcher described and analyzed the learners' responses concerning their perceptions and attitudes towards the implementation of weblogs in translation teaching and learning.

\section{Data Collection Method and Procedures}

Since the study aimed to deduce learners' attitudes towards utilizing weblogs in translation teaching and learning, the researcher used the most appropriate tool for that purpose which is the questionnaire. It was the main and only data collection instrument in this study. The questionnaire consisted of three parts. The first part was about learners' attitudes towards weblogs. It contained nine statements. Regarding the second part of the questionnaire, it was concerned about learners' attitudes towards translation on weblog versus translation on paper. This part included thirteen items. The third part of the questionnaire consisted of thirteen items. They were dedicated to teacher's and peers' feedback on the weblog. The total number the items was thirty five with a five-point Likert-scale ( $5=$ Strongly Agree, $4=$ Agree, $3=$ Not Sure, $2=$ Disagree, $1=$ Strongly Disagree). The questionnaire was not built from scratch. It was adopted from a previous study (Aljumah, 2012) with fundamental modification; some items were deleted and others were added in order to suit the purpose of this study. It was also re-evaluated by two professors of TESOL in the curriculum and instruction department, college of education, King Saud University in order to ensure the instrument appropriate validity. At the end of the semester, learners were handed the questionnaire and were asked to give their accurate responses. All the learners $100 \%$ (eleven female learners) responded to the questionnaire in the presence of the researcher who monitored the whole class and provided clarification to vague points.

\section{FINDINGS}

The questionnaire was administered to 11 female learners, senior college students majoring in English language at a Yemeni University. A descriptive statistic was used to analyse their responses to the questionnaire's items. The items addressed the learners' attitudes towards the implementation of weblogs on translation teaching and learning, the comparison between translation on weblog and translation on paper in class, and the learners' perceptions on the teacher's and learners' feedback on weblog. 


\section{Learners' attitudes towards the use of weblog in translation}

Learners were asked to respond to 9 five-point Likert-type items measuring their attitudes towards the implementation of weblogs in translation instruction as seen in Table 2.

Table 2

Mean Score of Learners' Attitudes towards the Use of Weblog in Translation

In general, learners showed positive attitudes towards the use of weblogs in translation teaching and learning. The highest mean score was 4.73 for Item 1 and Item 3 of Table 2 indicating that the majority of respondents ( $72.7 \%$ strongly agree) felt happy to use weblogs for translation and also felt comfortable writing their translation on the blog. The second highest mean score was 4.64 for Item 5; showing that more than two-thirds of the learners (63.6\% strongly agree) thought that weblog was a useful tool for sharing translation with others online. Also, 54.5\% strongly agree and $36.4 \%$ agree that posting a comment on the weblog was very easy. Another mean score was 4.27 , where the

\begin{tabular}{|c|c|c|c|c|c|c|}
\hline \multirow[t]{2}{*}{ İtems } & $\begin{array}{l}\text { Strongly } \\
\text { Agree }\end{array}$ & Agree & $\begin{array}{l}\text { Not } \\
\text { Sure }\end{array}$ & Disagree & \multicolumn{2}{|c|}{$\begin{array}{l}\text { Strongly } \\
\text { Disagree }\end{array}$} \\
\hline & $\mathrm{N}(\%)$ & $\mathrm{N}(\%)$ & $\mathrm{N}(\%)$ & $\mathrm{N}(\%)$ & $\mathrm{N}(\%)$ & M. (SD) \\
\hline $\begin{array}{l}\text { 1. I am happy to use the weblog for } \\
\text { translation. }\end{array}$ & $8(72.7)$ & $3(27.3)$ & $0(0)$ & $0(0)$ & $0(0)$ & $4.73(.467)$ \\
\hline $\begin{array}{l}\text { 2. I feel it is quite easy to post a comment on } \\
\text { the blog. }\end{array}$ & $6(54.5)$ & $4(36.4)$ & $1(9.1)$ & $0(0)$ & $0(0)$ & $4.45(.467)$ \\
\hline $\begin{array}{l}\text { 3. I feel comfortable writing my translation on } \\
\text { the blog. }\end{array}$ & $8(72.7)$ & $3(27.3)$ & $0(0)$ & $0(0)$ & $0(0)$ & $4.73(.467)$ \\
\hline $\begin{array}{l}\text { 4. Doing translation on weblog is enjoyable } \\
\text { and interesting. }\end{array}$ & $5(45.5)$ & $4(36.4)$ & $2(18.2)$ & $0(0)$ & $0(0)$ & $4.27(.467)$ \\
\hline $\begin{array}{l}\text { 5. I feel that blog is a useful tool for me to } \\
\text { share my translation with others online. }\end{array}$ & $7(63.6)$ & $4(36.4)$ & $0(0)$ & $0(0)$ & $0(0)$ & $4.64(.786)$ \\
\hline $\begin{array}{l}\text { 6. Translation industry will surely be } \\
\text { improved by the use of blogs in future. }\end{array}$ & $6(54.5)$ & $2(18.2)$ & $3(27.3)$ & $0(0)$ & $0(0)$ & $4.27(.505)$ \\
\hline $\begin{array}{l}\text { 7. Using blogs for translation is a waste of } \\
\text { time. }\end{array}$ & $0(0)$ & $0(0)$ & $1(9.1)$ & $4(36.4)$ & $6(54.5)$ & $1.55(.9 .5)$ \\
\hline $\begin{array}{l}\text { 8. I like the fact that the Weblog will make my } \\
\text { translations seen by online audience. }\end{array}$ & $5(45.5)$ & $2(18.2)$ & $3(27.3)$ & $1(9.1)$ & $0(0)$ & $4.00(.668)$ \\
\hline $\begin{array}{l}\text { 9. I think weblog is an interesting teaching } \\
\text { strategy for enhancing cooperative learning. }\end{array}$ & 7 (63.6) & $2(18.2)$ & $1(9.1)$ & $0(0)$ & $1(9.1)$ & $\begin{array}{l}4.27 \\
(1.095)\end{array}$ \\
\hline General mean score & & & & .10 & & \\
\hline
\end{tabular}

majority of learners (45.5\% strongly agree and $36.4 \%$ agree) thought that doing translation on weblog was very interesting. A similar mean score for Item 9 , indicates that the majority of learners $(36 \%$ strongly agree and $18.2 \%$ agree) believed that weblog was an interesting teaching strategy for enhancing cooperative learning. Another similar mean score for Item 6 shows that more than $70 \%$ thought that the translation industry would be improved by the use of blogs in future. When learners were asked if "Using blogs for translation is a waste of time", the majority of learners rejected this statement $(54.5 \%$ strongly disagree and $36.4 \%$ disagree) which means that they really thought that weblog was a practical application for practicing translation. Moreover, a mean score of 4 for Item 8 indicates that about two-thirds of the learners liked the fact that their translation would be seen by online users. Therefore, they enjoyed using weblog to share their translation with other online users. 


\section{Learner's attitudes towards translation on weblogs vs. translation on paper}

Table 3 presents the mean score of the participants' responses regarding their favourite method of practicing translation.

Table 3

Mean Score of Learners' Preferences on Translation on Weblog vs. Translation on Paper

Generally, learners enjoyed practicing translation on weblogs and had positive perceptions towards translation learning by means of blogging strategy. The majority of learners preferred the blogging strategy to the traditional one in translation teaching and learning. The highest mean score was 4.73

\begin{tabular}{|c|c|c|c|c|c|c|}
\hline \multirow[t]{2}{*}{ İtems } & \multirow{2}{*}{$\begin{array}{c}\text { Strongly } \\
\text { Agree }\end{array}$} & \multirow{2}{*}{$\begin{array}{c}\text { Agree } \\
\mathrm{N}(\%)\end{array}$} & \multirow{2}{*}{$\begin{array}{c}\text { Not } \\
\text { Sure } \\
\text { N (\%) }\end{array}$} & \multirow{2}{*}{$\begin{array}{l}\text { Disagree } \\
\mathrm{N}(\%)\end{array}$} & \multicolumn{2}{|c|}{$\begin{array}{l}\text { Strongly } \\
\text { Disagree }\end{array}$} \\
\hline & & & & & $\mathrm{N}(\%)$ & M. (SD) \\
\hline $\begin{array}{l}\text { 1. I prefer to practice translation on } \\
\text { the blog rather than in the class }\end{array}$ & $2(18.2)$ & $5(45.5)$ & $2(18.2)$ & $2(18.2)$ & $0(0)$ & $\begin{array}{l}3.64 \\
(1.027)\end{array}$ \\
\hline $\begin{array}{l}\text { 2. I feel that my translation is better when } \\
\text { translating on the weblog than translating on } \\
\text { paper in class }\end{array}$ & $4(36.4)$ & $2(18.2)$ & $4(36.4)$ & $1(9.1)$ & $0(0)$ & $\begin{array}{l}3.82 \\
(1.079)\end{array}$ \\
\hline $\begin{array}{l}\text { 3. I can be more creative when translating on } \\
\text { the blog than on paper. }\end{array}$ & $4(36.4)$ & $2(18.2)$ & $3(27.3)$ & $2(18.2)$ & $0(0)$ & $\begin{array}{l}3.73 \\
(1.191)\end{array}$ \\
\hline $\begin{array}{l}\text { 4. I can get help when I translate on the blog } \\
\text { like in the class }\end{array}$ & $4(36.4)$ & $5(45.5)$ & $2(18.2)$ & $0(0)$ & $0(0)$ & $4.18(.751)$ \\
\hline $\begin{array}{l}\text { 5. I feel no pressure when translating on the } \\
\text { blog because I have more time to consult } \\
\text { dictionaries online }\end{array}$ & $6(54.5)$ & $4(36.4)$ & $1(9.1)$ & $0(0)$ & $0(0)$ & $4.45(.688)$ \\
\hline $\begin{array}{l}\text { 6. I can produce more accurate translation } \\
\text { when translating on the blog than on paper }\end{array}$ & $4(36.4)$ & .2) & 4) & ) & $0(0)$ & $\begin{array}{l}3.82 \\
(1.079)\end{array}$ \\
\hline $\begin{array}{l}\text { 7. I feel free to translate on the blog than in } \\
\text { the class }\end{array}$ & $2(18.2)$ & 4) & 4) & f & $0(0)$ & 3.64 \\
\hline $\begin{array}{l}\text { 8. I have improved my translation skills since } \\
\text { I began blogging }\end{array}$ & $2(18.2)$ & $5(45.5)$ & $3(27.3)$ & $1(9.1)$ & $0(0)$ & $3.73(.905)$ \\
\hline $\begin{array}{l}\text { 9. I am more active in checking up meaning } \\
\text { of difficult words in the dictionary when } \\
\text { blogging }\end{array}$ & $4(36.4)$ & $6(54.5)$ & $0(0)$ & $1(9.1)$ & $0(0)$ & 4.18 \\
\hline $\begin{array}{l}\text { 10. I am more careful with my translation } \\
\text { when blogging }\end{array}$ & $4(36.4)$ & $4(36.4)$ & $1(9.1)$ & $2(18.2)$ & $0(0)$ & $\begin{array}{l}3.91 \\
(1.136)\end{array}$ \\
\hline $\begin{array}{l}\text { 11. I always check my translated text before I } \\
\text { post it on the blog }\end{array}$ & $9(81.8)$ & $1(9.1)$ & $1(9.1)$ & $0(0)$ & $0(0)$ & $4.73(.647)$ \\
\hline $\begin{array}{l}\text { 12. I don't like to check my translation when } \\
\text { I translate on paper }\end{array}$ & $0(0)$ & $1(9.1)$ & $2(18.2)$ & $6(54.5)$ & $2(18.2)$ & $2.18(.874)$ \\
\hline $\begin{array}{l}\text { 13. When I translate on the blog, I don't } \\
\text { worry about mistakes }\end{array}$ & $1(9.1)$ & $3(27.3)$ & $2(18.2)$ & $4(36.4)$ & $1(9.1)$ & $\begin{array}{l}3.18 \\
(1.250)\end{array}$ \\
\hline General Mean Score & & & & .78 & & \\
\hline
\end{tabular}

for Item 11, indicating that the majority of learners (90.9\% strongly agree and agree) always checked their translation when blogging before posting it on the weblog, on the other hand a lower percentage (72.7\% strongly disagree and disagree) was expressed when asked on Item 12 "I do not like to check my translation when I translate on paper". This percentage informs us that learners were more careful in checking their translation on weblog and did not like to make mistakes when they were translating on weblogs and this was also enforced by Item 13 which shows that $48.5 \%$ of the learners felt worried to make mistakes on weblog translation while $36.4 \%$ did not worry of making mistakes and $18.2 \%$ were not sure about being worried of making mistakes while translating on weblog. The second 
highest mean score was 4.45 for Item 5, which indicates that more than $90 \%$ of learners agree and strongly agree that Blogging Assisted Translation Teaching and Learning (BATTL) was a preferable strategy because it did not cause learners to be under pressure of time. Therefore they could consult online dictionaries and made their translation more accurate and acceptable. Moreover, the majority of learners (36.4\% strongly agree and 54.5\% agree with a mean score of 4.18) were more active in checking up meanings of difficult words when practicing translation on weblogs (Item 9). A similar mean score for Item 4 shows that learners could get help when blogging similarly as when practicing translation in class. Regarding the creativity that weblog facilitated for translation students, more than half of the participants of this study (54.6\% agree and strongly agree) felt that they were more creative when practicing translation on the weblog. In addition, when learners were asked if their translation had improved since starting blogging (Item 8), almost two-thirds of the participants (63.7\% agree and strongly agree) thought that their translation really developed since they began practicing translation on weblog. In the same way, on Item 1, the same percentage (63.7\% agree and strongly agree) indicates that learners preferred the BATTL to the traditional method of translation teaching and learning. As a response to Item 7, more than half of the participants (54.6\%) agree and strongly agree that they felt free when translating on the weblog.

\section{Teacher's and peers' feedback in BATTL.}

Since feedback is a very important factor in teaching and learning process, the researcher dedicated this section of the questionnaire to the feedback that learners receive from their teacher and peers as well. It includes 13 five Likert-point items as seen in Table 4.

Table 4

Mean Score of Teacher's and Learners' Feedback in BATTL

\begin{tabular}{|c|c|c|c|c|c|c|}
\hline \multirow[t]{2}{*}{ İtems } & \multirow{2}{*}{$\begin{array}{c}\text { Strongly } \\
\text { Agree } \\
\text { N ( \%) }\end{array}$} & \multirow{2}{*}{$\begin{array}{l}\text { Agree } \\
\text { N (\%) }\end{array}$} & $\begin{array}{l}\text { Not } \\
\text { Sure }\end{array}$ & Disagree & \multicolumn{2}{|l|}{$\begin{array}{l}\text { Strongly } \\
\text { Disagree }\end{array}$} \\
\hline & & & $\mathrm{N}(\%)$ & $\mathrm{N}(\%)$ & $\mathrm{N}(\%)$ & M. (SD) \\
\hline $\begin{array}{l}\text { 1. I really like to receive feedback from my } \\
\text { translation teacher. }\end{array}$ & $8(72.7)$ & $3(27.3)$ & $0(0)$ & $0(0)$ & $0(0)$ & $4.73(.467)$ \\
\hline $\begin{array}{l}\text { 2. The teacher's feedback on the weblog is helpful } \\
\text { for me and my friends. }\end{array}$ & $8(72.7)$ & $3(27.3)$ & $0(0)$ & $0(0)$ & $0(0)$ & $4.73(.467)$ \\
\hline $\begin{array}{l}\text { 3. I enjoyed reading my classmates' comments on } \\
\text { the weblog. }\end{array}$ & $8(72.7)$ & $3(27.3)$ & $0(0)$ & $0(0)$ & $0(0)$ & $4.73(.467)$ \\
\hline $\begin{array}{l}\text { 4. Reading the comments of my peers on the blog } \\
\text { help me to learn and improve my translation skills. }\end{array}$ & $8(72.7)$ & $2(18.2)$ & $1(9.1)$ & $0(0)$ & $0(0)$ & $4.64(.674)$ \\
\hline $\begin{array}{l}\text { 5. My classmates' comments on the web blog were } \\
\text { unpleasant. }\end{array}$ & $0(0)$ & $2(18.2)$ & $0(0)$ & $4(36.4)$ & $5(45.5)$ & $1.91(1.136)$ \\
\hline $\begin{array}{l}\text { 6. My peers' feedback discouraged me to post more } \\
\text { translations. }\end{array}$ & $2(18.2)$ & $1(9.1)$ & $2(18.2)$ & $2(18.2)$ & $4(36.4)$ & $2.55(1.572)$ \\
\hline $\begin{array}{l}\text { 7. I like having classmates make comments on my } \\
\text { translation. }\end{array}$ & $9(81.8)$ & $1(9.1)$ & $1(9.1)$ & $0(0)$ & $0(0)$ & $4.73(.647)$ \\
\hline $\begin{array}{l}\text { 8. I don't have to worry of what my friends would } \\
\text { think of my language when I translate on the blog. }\end{array}$ & $9(81.8)$ & $2(18.2)$ & $0(0)$ & $0(0)$ & $0(0)$ & $4.82(.405)$ \\
\hline $\begin{array}{l}\text { 9. I feel uncomfortable about my classmates' } \\
\text { comments on my translation. }\end{array}$ & $1(9.1)$ & $2(18.2)$ & $0(0)$ & $2(18.2)$ & $6(54.5)$ & $2.09(1.514)$ \\
\hline 10. My teacher's feedback is not constructive. & $1(9.1)$ & $0(0)$ & $1(9.1)$ & $4(36.4)$ & $5(45.5)$ & $1.91(1.221)$ \\
\hline $\begin{array}{l}\text { 11. I enjoy discussing ideas about my translation } \\
\text { with my peers. }\end{array}$ & $10(90.9)$ & $1(9.1)$ & $0(0)$ & $0(0)$ & $0(0)$ & $4.91(.302)$ \\
\hline 12. I trust my teacher's feedback on my translation. & $9(81.8)$ & $2(18.2)$ & $0(0)$ & $0(0)$ & $0(0)$ & $4.82(.405)$ \\
\hline 13. I trust my peer's feedback on my translation. & $6(54.5)$ & $5(45.5)$ & $0(0)$ & $0(0)$ & $0(0)$ & $4.55(.522)$ \\
\hline General Mean Score & & & & .93 & & \\
\hline
\end{tabular}


The highest mean score was 4.91 for Item 11, and this indicates that the majority of the participants (90.9\% strongly agree) enjoyed discussing ideas about their translation with their peers. The second highest mean score was 4.81 for Item 8 showing that the majority of the participants $(81.8 \%$ strongly agree) did not have to worry of what their peers think of their language when they were translating on the weblog. A similar high mean score (4.82) for Item 12 shows a very high percentage of $81.8 \%$ strongly agree in trusting their teacher's feedback on their translation on the weblog. They also expressed a strong rejection (more than $81 \%$ disagree and strongly disagree) when asked that their teacher's feedback was not constructive (Item 10). When it comes to trusting peer feedback, more than half of the participants (54.5\% strongly agree) trusted their peers' feedback on their translation (Item 13), and about two-thirds of the learners (64.6\%) did not feel that their peers' feedback discouraged them to post more translation on the weblog (Item 6). It is clear from the percentages expressed in trusting teacher's and peers' feedback that learners gave a higher trust to their instructor's feedback than to their peers. Moreover, the first and the second items had the same percentage ( $72.7 \%$ strongly agree and $27.3 \%$ agree) and a mean score of 4.73 , indicating that the learners really liked to receive feedback from their translation teacher. They also felt that their teacher's feedback on the weblog was helpful for all of them. Regarding Item 3 which has a mean score of 4.73, the majority of the participants (72.7\% strongly agree) enjoyed reading their peers' comments on the weblog. Furthermore, they thought that reading their peers' comments helped them improve their translation skills (Item 4). Similarly, the majority of the learners (36.4\% disagree and $45.5 \%$ strongly disagree) did not think that their friends' comments were unpleasant (Item 5). Regarding the learners' feeling towards their friends' comments on their translation, the majority of the learners $(54.5 \%$ strongly disagree and 18.2 disagree) did not feel uncomfortable about their peers' comments on their translation (Itme9); they really liked having their classmates make comments on their translation.

\section{DISCUSSION}

This study aimed to deduce learners' attitudes and perceptions towards the utilization of blogs in translation teaching and learning (BATTL). There were three questions answered in this study. The findings of this study were discussed in this section.

For the first question, "What type of perceptions and attitudes learners have towards the implementation of weblogs on the translation course?", the questionnaire results indicated that learners enjoyed the blogging experience and felt comfortable using this new application. Though blogging for learners was a new experience, they really liked it, especially for sharing their translations with others online. Learners also found blogging an interesting and practical means for learning; this could be because it is easy to use and freely accessible. Therefore, it could be concluded that the Yemeni female learner participants had positive attitudes towards implementing weblogs on translation classes. The findings of this study confirmed the findings of previous studies which investigated the learners' attitudes towards using weblogs in language learning (Pinkman, 2005; Noytim, 2010; Aljumah, 2012).

Regarding the second question "What are the learners' attitudes towards using weblogs in translation in comparison with the traditional method?", the questionnaire results informed us that learners preferred the blogging strategy to the traditional one in translation teaching and learning because they thought that they were more careful and accurate when translating on weblog. Learners were keen to check their translation both on paper and on weblog; however, the learners were keener when posting their translated texts on blog. This could be due to the fact that their posts would be seen by a bigger audience online. Although the learners showed their keenness to check their translation before posting them on blog, merely less than the half of the participants (48\%) were worried about committing mistakes. This unconcernedness of making errors might be resulted from learners' high expectations to receive a constructive feedback from the tutor and peers. Another feature that made learners prefer translation strategy through blogging was the time. In other words, when learners were posting their 
translated texts, they were not under pressure of time, which as a result allowed them to consult online dictionaries and edit their translation, and then produce good work. Though more than half of the learners believed that they were more creative and free, and producing better translation while blogging, almost one-third of the participants (36.4\%), on the other hand, felt unsure about that. The researcher would relate such unsureness of producing better translation and feeling free and creative when translating on blog to the limited translation practice learners spent on the weblog. They just practiced translating a total number of six texts.

In general, the analysis of the results showed that learners believed they produced better translation when blogging. This result agreed with the previous studies which investigated the learners' improvement in writing skill via weblog (Pinkman, 2005; Noytim, 2010; Kitchakarn, 2012).

For the last question of the present study, "What are learners' attitudes towards teacher's and peers' feedback via weblog in translation classes?", the questionnaire results indicated that learners had positive attitudes towards teacher's and peers' feedback. This can be clearly observed from the learners' responses to section three of the questionnaire, which was concerned with the teacher's and peer's feedback via weblog. The learners enjoyed discussing their comments with peers and were happy to receive feedback from their peers and teacher as well. This told us that they had positive attitudes towards their peers' and teacher's feedback via the weblog. They also liked to receive feedback from their teacher and peers because learners thought that the teacher's and peers' feedback on their translation was very helpful. Though learners trusted both the peers' and teachers' feedback, they gave a higher trust to their teacher's feedback ( $81.8 \%$ strongly agree) than to their peers' feedback (54.5\% strongly agree). This higher trust given to the teacher's feedback could be resulted from the nature of the teacher's role in providing quality feedback. This finding agreed with Hyland and Hyland (2006) who explained that learners preferred teachers' feedback to their peers' because learners believed that feedback was the teacher's responsibility.

Generally, learners had positive attitudes towards their teacher's and peers' feedback. This finding supported the previous study of Noytim (2010). On the other hand, the present study contradicted with the study of Lin, Groom and Lin (2013) who reported negative results regarding the peer feedback and learners' interaction in the blogging process. They claimed that low-level learners were reluctant to give feedback to their peers because they were afraid of committing mistakes. Such contradicting results stressed the importance of creating an encouraging and safe environment, so low- level learners would participate and give feedback, regardless of committing errors. Learners should feel motivated and safe in order to effectively take part in class activities and get feedback from peers and teachers.

\section{CONCLUSION}

The analysis of the results indicated that Yemeni University EFL learners who participated in the study had positive attitudes toward the Blog Assisted Translation Teaching and Learning (BATTL). They liked experiencing blogging in translation class and felt happy using this up-to-date technology (Question1).

Furthermore, the analysis of learners' responses showed that learners' preferences regarding the translation teaching strategies were positive toward BATTL. They believed that BATTL was a good strategy for improving translation skills. They also believed that practicing translation via weblogs played an important role in making their translation better and more accurate (Quesiton2).

The results also showed that students had positive attitudes toward their teacher's feedback on their translation via weblog. They also had positive attitudes towards their peers' feedback. They strongly believed that through reading their peers' comments, their translation skills had improved drastically (Question 3). 


\section{Suggestions for further research}

Based on the findings of this study, further work is still needed to improve translation learning and teaching. The following are some suggestions for related future studies:

First, this study was conducted upon a very small group of participants. Replicating the study with a bigger sample of EFL students is needed to have more applicable results.

Second, this study dealt with advanced EFL learners. A similar study could deal with lower levels where learners take the first translation course.

Third, this study focused on female learners. A similar study can be conducted upon male learners to see if there is a difference between the attitudes of female learners and those of male learners towards BATTL.

Fourth, this study investigated learners' attitudes toward implementing weblogs in translation. Another experimental study could be executed to find the effectiveness of Blogging on the accuracy and quality of learner's translation.

\section{REFERENCES}

Al-Hamdallah, R. (1998). Problems and approaches to translation with special reference to Arabic. Journal of King Saud University, Lang. Transl., 10, 23-38.

Aljumah F. (2012). Saudi learner perceptions and attitudes towards the use of weblogs in teaching English writing course for EFL majors at Qassim University. English language teaching, 5(1), 100116.

Al-Nakhalah, A. M. (2013). Investigating the difficulties and problems faced by English language students of Al Quds Open University in legal translation process. The International Journal of English Language \& Translational Studies, 1(3), 166-185.

Alshumaimeri, Y. (2008). Perceptions and attitudes toward using CALL in English classrooms among Saudi secondary EFL teachers. The JALT CALL journal, 4(2), 29-46.

Amir, Z., Ismail, K., \& Hussin, S. (2011). Blogs in language learning: Maximizing students' collaborative writing. Procedia - Social and Behavioral Sciences, 18, 537-543. https://doiorg.sdl.idm.oclc.org/10.1016/j.sbspro.2011.05.079

Azizinezhad, M. \& Hashemi, M. (2011). The use of weblogs in teaching and learning translation. Procedia - Social and Behavioral Sciences, 28, 867-871. https://doiorg.sdl.idm.oclc.org/10.1016/j.sbspro.2011.11.159

Campbell, A.P. (2003). Weblogs for use with ESL classes. The Internet TESL journal. Retrieved from http://iteslj.org/Techniques/Campbell-Weblogs.html

Ducate, L. \& Lomicka, L. (2005). Exploring the blogosphere: Use of blogs in the foreign language classroom. Foreign Language Annals, 38(3), 410-421.

Fellner, T., \& Apple, M. (2006). Developing writing fluency and lexical complexity with weblogs. The JALT CALL Journal, 2(1), 15-26.

Grami G. M. (2012). Online collaborative writing for ESL learners using weblogs and feedback checklists. English Language Teaching, 5(10), 43-48. 
Hanrahan, S. \& Isaacs, G. (2001). Assessing self-and peer-assessment: The students' view. Higher Education Research \& Development, 20(1), 53-66.

Hyland, F. \& Hyland, K. (2006). State of the art article: Feedback on second language students' writing. Language Teaching, 39, 83-101.

Jimoyiannis A. \& Angelaina S. (2012). Toward an analysis framework for investigating students' engagement and learning in educational weblogs. Journal of computer Assisted learning, 28, 222-234.

Kim, H.N. (2008). The phenomenon of blogs and theoretical model of blog use in educational contexts. Computers\& Education, 51(3), 1342-1352.

Kitchakarn, O. (2012). Using blogs to improve students' summary writing abilities. Turkish Online Journal of Distance Education-TOJDE, 13, 209-219.

Lin, M. H., Groom, N., \& Lin, C.-Y. (2013). Blog-assisted learning in the ESL writing classroom: A phenomenological analysis. Educational Technology \& Society, 16 (3), 130-139.

Liu, N. \& Carless, D. (2006). Peer feedback: The learning element of peer assessment. Teaching in Higher Education, 11(3): 279-290.

McDonough Dolmaya, J. (2011). A window into the profession: What translation blogs have to offer translation studies. The Translator 17(1), 77-104.

Noytim, U. (2010). Weblogs enhancing EFL students' English language learning. Procedia- Social and Behavioral Sciences, 2(2), 1127-1132. org.sdl.idm.oclc.org/10.1016/j.sbspro.2010.03.159

Oravec, J. A. (2003). Blogs as an emerging genre in higher education. Journal of Computing in Higher Education, 14(2): 21-44.

Oro Cabanas, J. M. (2012). Errors in translation: A tool for linguistic and socio-cultural competence. International Journal of Applied Linguistics \& English Literature, 1(1), 90-103.

Perrino, S. (2009). User-generated translation: The future of translation in a Web 2.0 environment. The Journal of Specialised Translation, 12, 55-78.

Pinkman K. (2005). Using weblogs in the foreign language classroom: Encouraging learner independence. The JALT Journal, 1 (1), 12-24.

Richardson, W. (2010). Blogs, wikis, podcasts and other powerful web tools for classrooms ed.). Thousand Oaks, California: Corwin Press.

Roussinos D. \& Jimoyiannis A. (2011). Blended collaborative learning through a wiki-based project: A case study on students' perceptions. International Journal of Digital Literacy and Digital Competence 2, 15-30.

Schroeder A., Minocha S. \& Schneider C. (2010). The strengths, weaknesses, opportunities and threats of using social software in higher and further education teaching and learning. Journal of Computer Assisted Learning 26, 159-174.

Taki, S. \& Fardafshari, E. (2012). Weblog-based collaborative learning: Iranian EFL learners' writing skill and motivation. International Journal of Linguistics, 4(2), 412-429. 
Ward, J. (2004). Blog assisted language learning (BALL): Push button publishing for the pupils. TEFL Web Journal, 3(1), 1-16.

Wu, C. (2006). Blogs in TEFL: A new promising vehicle. US-China Education Review, 3(5), 69-73.

Yunus, M. M., Tuan, J. L. K. \& Salehi, H. (2013). Using blogs to promote writing skill in ESL classroom. Retrieved May 9, 2014 from http://arxiv.org/ftp/arxiv/papers/1305/1305.6358.pdf. 